\begin{tabular}{|l|l|l||}
\hline \multicolumn{2}{|c|}{ PublisherInfo } \\
\hline \hline PublisherName & $:$ & BioMed Central \\
\hline \hline PublisherLocation & $:$ & London \\
\hline \hline PublisherImprintName & $:$ & BioMed Central \\
\hline \hline
\end{tabular}

\title{
Biobank debate heats up
}

\begin{tabular}{|l|c|l||}
\hline \multicolumn{2}{|c|}{ ArticleInfo } \\
\hline \hline ArticleID & $:$ & 4744 \\
\hline \hline ArticleDOI & $:$ & $10.1186 /$ gb-spotlight-20030408-02 \\
\hline \hline ArticleCitationID & $:$ & spotlight-20030408-02 \\
\hline \hline ArticleSequenceNumber & $:$ & 96 \\
\hline \hline ArticleCategory & $:$ & Research news \\
\hline ArticleFirstPage & $:$ & 1 \\
\hline \hline ArticleLastPage & $:$ & 3 \\
\hline \hline & & RegistrationDate : 2003-4-8 \\
\hline ArticleHistory & $:$ & OnlineDate \\
\hline \hline ArticleCopyright & $:$ & BioMed Central Ltd2003-4-8 \\
\hline \hline ArticleGrants & $:$ & \\
\hline \hline ArticleContext & $:$ & 130594411 \\
\hline \hline
\end{tabular}




\section{Pat Hagan}

Email: pat.hagan@btconnect.com

The new head of the UK Biobank has tried to ease concerns that the project is an over-ambitious waste of money that is draining vital research funding away from other areas of science.

John Newton, appointed chief executive officer earlier this year, used his first public appearance last night (April 7) to outline the potential of the project to save lives and transform the treatment of illnesses. He told a meeting of politicians, academics and industry leaders that the bank - which involves collecting DNA samples from 500,000 middle-aged people in the UK - could allow scientists to pinpoint specific factors involved in certain diseases, ultimately leading to new and better treatments.

The meeting, organised by MPs, took place in response to calls for a public debate on the $£ 45$ million Biobank project. Last month, the House of Commons Science and Technology Committee launched a scathing attack on the Medical Research Council (MRC), which is managing the initiative. The committee accused the MRC of poor financial management, and said the evidence suggested the Biobank scheme was "a politically-driven project."

But Newton insisted that, in the long run, it would reap benefits. He told the meeting: "The UK Biobank is not a single study, or even a single project, but a resource for the biomedical research community for the first few decades of this century. Its true value may not be realized for some 30 years. But every generation has the responsibility to plant shade trees for the next."

According to Newton, the real advantage of such a precious database will be in studying the associations between discrete environmental, lifestyle and genetic factors and the way they interact. "This will allow the risk of disease to be predicted in populations. Predicting risk in individuals is not the aim of the study. Knowing difference in risk in populations can provide direct evidence for the scope of prevention. ...The power of the UK Biobank is that its design provides the most powerful means of identifying the true causes of disease."

As an indication of what he hopes it will achieve, Newton drew parallels with the Framingham study of the 1960s, which eventually linked high cholesterol with heart disease and paved the way for the development of lipid-lowering drugs. "Now we have drugs that reduce cholesterol and heart disease risk by $30 \%$ in some groups. If the UK Biobank generated just one finding of this significance it would have been worthwhile in public health terms."

But critics remained unconvinced. Helen Wallace, from the pressure group Genewatch UK, told the same meeting there was no evidence to suggest that pumping millions of pounds into the gene bank would be as beneficial as spending it on well-targeted public health initiatives to prevent illness. "We still feel there are some key issues that need to be addressed before it goes ahead," Wallace told us. "One is whether it will deliver the health benefits they claim and the other is the need for new laws to prevent discrimination by insurers and employers - at the moment there's no legislation even on the table."

Wallace also said the analogy with the cholesterol studies is misleading, because they produced findings on which doctors were able to act. "They are not going to be finding something that can be lowered, just genetic make-up that cannot be changed," she warned. 
Ian Gibson, Labour MP for Norwich and chairman of the Science and Technology committee, told us he too remains unconvinced by Newton's comments. He said the MRC still needs to convince the public and large sections of the scientific community that the project will reap benefits in the long-term, and work hard to persuade would-be volunteers to sign up for the initiative.

"The meeting opened his [Newton's] eyes a bit about what he needs to do and what problems people are worried about. He knows now and will have to go about addressing them. There's a lot of public relations to be done to get the message across," said Gibson.

\section{References}

1. UK Biobank, [http://www.ukbiobank.ac.uk/]

2. UK Biobank chief executive officer appointed, [http://www.ukbiobank.ac.uk/documents/ 2403_UK_biobank_\%20CEO_announcement.doc]

3. House of Commons Science and Technology committee, [http://www.parliament.uk/ parliamentary_committees/science_and_technology_committee.cfm]

4. P. Hagan, "MRC under attack," The Scientist, March 25, 2003., [http://www.the-scientist.com/news/ 20030325/04/]

5. Medical Research Council, [http://www.mrc.ac.uk/]

6. Framingham heart study, [http://www.nhlbi.nih.gov/about/framingham/]

7. Genewatch UK, [http://www.genewatch.org/]

8. Hagan P: Tracking genes and disease. The Scientist, January 21, 2002., [http://www.thescientist.com/news/20020121/03/]

9. Gavaghan H: Cut and thrust of parliamentary life. The Scientist, February 18, 2003., [http://www.thescientist.com/news/20030218/06/] 